\title{
Growth Effects of Remittance: A Case of Turkey Diaspora
}

\author{
Dr. Caterina De Lucia \\ Department of Economics, University of Foggia, Foggia, Italy
}

\author{
Mr. Luigi Pio Leonardo Cavaliere* \\ Department of Economics, University of Foggia, Foggia, Italy \\ *Corresponding author. Contact e-mail: luigi.cavalie@gmail.com
}

\author{
Ms. Ester Salvato \\ Department of Economics, University of Foggia, Foggia, Italy
}

\section{Dr. Alessio Faccia}

School of Business and Law, Coventry University, Coventry, United Kingdom

\begin{abstract}
In the age of globalization, remittances are an essential part of human life. This analysis's key objective is to examine the effect of remittances in developing economies like Turkey on economic development. The 1980 to 2020 time-series data used in this analysis which use numerous time series estimating techniques. Sending data is given by the Banks of Turkey and in a million dollars. Simultaneously, economic development or GDP data are provided by world economic indicator, the World Bank, and the new US dollar. The findings indicated that there are both shortterm and long-term ties between transactions and economic development in Turkey. Therefore, results indicate that Turkey's transition flows positively affect Turkey's person and Turkey's macroeconomic scenario. The government should implement policies that allow Turkey in overseas countries to submit transmissions through official channels.
\end{abstract}

Keywords

Economic growth; Remittances; Autoregressive Distributed Lag analysis

Article Received: 10 August 2020, Revised: 25 October 2020, Accepted: 18 November 2020

\section{Introduction}

Remittances are one of the main foreign exchange streams, usually insufficient savings on their investment, in the underdeveloped and developing countries. Development countries are expected to earn US\$435 billion in 2014 and US\$454 billion in 2015. (World Bank, 2014). For the underdeveloped and emerging countries; thus, transfer flows are quite significant.

Sending's were also a significant foreign exchange outlet for Turkey, the output of which relied on the imported intermediate products and energy sources in 1978-2000. Over the period 1978-1998, payments to Turkey rose to 5,356 billion USD and then declined to 919 million USD in 2013.

Remittances can have a positive and negative effect on economic growth through direct and indirect channels. The biggest networks are as follows:

- Releases increase household sales, in turn boost consumption and therefore, through the multiplier process, have a significant effect on aggregate demand and economic development (Ar1 and Ozcan, 2012).

- Remittance investments indirectly impact economic growth (Woodruff and Zenteno, 2004). This channel reduces the detrimental effect on economic development of insufficient savings

- Remittances indirectly influence economic growth by that uncertainty, since remittances are not too volatile toward economic shifts in relation to FDI inflows and fund investments (Ramey and Ramey, 1995)
- Remittances indirectly impact economic growth by leading to financial sector production (Giuliano and Ruiz-Arranz, 2009).

Sendings, on the other hand, have had some detrimental influence on economic development. The Dutch disease is the most accentuated detrimental impact of payments on economic development. Dutch spending has influenced remittances (see Chowdhury and Rabbi (2014), Nikas and Blouchoutzi (2014), López et al. (2007)).

We analyse the effect of transactions along with foreign direct investment (FDI) inflows and gross domestic savings (GDS) on Turkish economic growth from 1974 to 2013, utilising the Autoregressive Distributed Lag (ARDL) method as a cointegration. The majority of the analysis is organised accordingly. The following segment discusses the latest literature on the connection between transactions and economic development. In Section III the data and process are introduced and addressed, in Section IV the analytical observations are presented, and in Section V the conclusion and policy consequences are given.

A significant number of studies have been undertaken on the connection between development and remittances in emerging and underdeveloped countries in particular. These experiments have provided mixed outcomes. The majority of the studies have found positive association between transfers and growth in economics (See Pradhan et al. (2008), Nsiah and Fayissa (2011), Nyamongo et al. (2012), Ar1 and Ozcan (2012), Goschin (2014), Salahuddin and Gow (2015)), although studies have found no correlation between economic growth and transfers (See IMF (2005), Ahamada and Coulibaly (2013), Kumar and other studies). 
Relatively few experiments have shown that the association between economic development and transactions is negative (see Chami et al. (2003), Karagoz (2009)).

Chami et al. (2003) studied the economic growth impact of remittances in 113 countries during the 1970-1998 era and found that the economic growth and remittances were negatively related by panel regression. On the other side, the IMF (International Monetary Fund) (2005) analysed the impact of remittances on economic growth in 101 developing countries in 1970-2003 and found that the association between economic growth and remittances was not statistically important.

Pradhan et al. (2008) analysed, by way of a panel regression, the influence of remittances on economic development in 39 developed countries and concluded that remittances significantly impacted economic growth. In 1970-2005, by using Johansene's co-integration, Karagoz (2009) analysed the influence of remittances on economic growth in Turkey and concluded that remittances had a negative impact on economic growth. Nsiah and Fayissa (2011) also studied, by implementing unit root checking, cointegration testing and fully adjusted ordinary lower squares, the effect on economic growth of remittances along with certain macroeconomic variables in 64 African, Asian, and Latin American Caribbean countries and found that remittances had a positive impact on economic growth.

Nyamongo et al. (2012) analysed the effect on economic growth in 36 African countries of remittances and financial development through panel regression in 1980-2009, and found that remittances had a positive impact on economic growth, whereas uncertainty in remittances had a detrimental impact on economic growth. The Ar1 and Ozcan (2012) studied, by means of a complex panel data study, the effect of remittances on economic development in thirty developed countries and concluded that remittances of the workforce had a positive impact on economic growth.

The causal association between economic growth and sending of funds was tested by Ahamada and Coulibaly (2013) in 20 sub-Saharan African countries in the period 1980-2007 using the Granger causality test and found that the causal connectivity between economic growth and sending of funds did not occur. Using a panel regression for the duration 1970-2004, Senbeta (2013) analysed the influence of remittances on economic determinants in 50 countries and noticed that the remittances had a favourable effect on capital accumulation statistically significant effect on overall productive element.

Kumar and Stauvermann (2014) analysed the effect of transfers in Bangladesh on economic growth in 1979-2012 using ARDL model. They found that long term transfers had a positive impact on economic growth and bidirectional causality between economic growth and transfers. On the other hand, in the period 1980-2012, Kumar and Vu (2014) analysed the relationship between sales and economic growth in Vietnam using the ARDL boundary test and Granger causality test and found that there was no longer a long-lasting relationship among economic growth and sending while the bidirectional causality between economic growth and sending was developed. Goschin (2014) also analysed the connection between economic growth and payments in 10 Central and Eastern Europe countries through a panel regression during the period 1996-2011 and found that payments had a beneficial effect on economic growth.

Lim and Simmons (2015) looked at the ties between the actual per capita GDP, expenditure and remittances, and found no long term association between real GDP per capita and remittances in 13 Caribbean Group and Traditional Market countries in 1975-2010 using co-integration tests of Pedroni and Westerlund. In comparison, Salahuddin and Gow (2015) analysed the relationship of economic growth with remittances in Bangladesh, India, Pakistan and the Philippines in the 1977-2012 timeframe by using cointegration panel tests of Pedroni and Westerlund and group average panel regression.

\section{Evaluate the issues of remittances}

There were three major fields in which a detailed review of Turkey's transition problems may be presented. The first field focuses on the transition infrastructure and emerging financial products and the second region explores the economic growth effect of transfers. The third region deals with the problems of strategy. The key determinants of worker remittances must be questioned at the outset of the debate on remittances. It is claimed that three key collections of variables reflect the movement of transfers: those relating to countries that send migrants, those connected with migrants themselves, and those who accept migrants. There are two primary sets of variables discussed in describing the core motivations behind the remittances 3: firstly, the dynamic of families' relations that suggest consumption smoothing and that have to do with social standing, security and risk-sharing of the individuals concerned. It is concluded that macroeconomic variables impact job transfer considerably, suggesting that labour exporting governments will control the inflow of funds by effective macroeconomic policies. In terms of policy effects, it is proposed that (a) sound exchange rate regimes, economic and political stability draw remittance flows; (b) expenditure motivations are more successful in the migration of staff to the country; and (c) consumption smoothing remains an affective trigger of remittance distribution.

\section{Remittance infrastructure and new financial products}

As of the early 1960 s, more than $\$ 75$ billion had been compensated back in Turkey, which is the current annual figure of $\$ 1.9$ billion (See Figures 1 and 2). However, the annual flow of remittances during this time has fluctuated from year to year, but has gradually risen in terms of the long-term pattern. The estimated annual cash flow rate in the 1970 s was about $\$ 1.5$, which grew to $\$ 2.3$ in the 1980 s and $\$ 3.3$ in the $1990 \mathrm{~s}$. Over the last three decades, overall payments have become a very significant addition to the Turkish economy, but are in comparatively low proportion. For example, although in the 1980s remittances constituted on average more than $65 \%$ of the trade gap and more than $2,5 \%$ of GNP, in the 1990's these estimates were less than $45 \%$ and below $2 \%$ respectively. In general, the flows of 
Transfers have not deteriorated markedly as migration streams matured in Turkey, but the country's remittance rate have been comparatively poor compared to tourism, exports and other income sources. Official estimates can repeatedly underestimate the scale of transfer flows, since they do not catch informal transfers. Increased foreign purchases, including daily flying, lead significantly to these forms of cash flows. Moreover, the official estimates do even not contain any money that migrants officially give back to Turkey. Sendings are commonly underreported globally. It is argued. Turkey is no exception. Turkey is no exception. On the basis of a context paper drawn up by the OECD Secretariat, some conclusions can be drawn about transactions through Turkish banks and other financial institutions (see Table 1). This paper shows that the Turkish banks are the largest transactions to Turkey. Is Bankasi and Ziraat Bankasi the two most important transfers which account for over half of the transfers to Turkey. The key goal of operations carried out by these banks tends to be to promote remittance transfers rather than to benefit the money of migrants. Thus, the Turkish banks prefer to retain transaction costs as minimal as possible, even smaller than their global equivalents. The costs of sending transactions to Turkey tend to differ from one bank to another and mostly because of the type of transaction used. The expense of move of money to Turkey is comparatively low compared to the transaction costs quoted by other reports worldwide (the average cost is $15 \%$ and $20 \%$ of the total volume expended). However, if migrants prefer to remit and submit regularly.

Tiny sums can also be implied with a move that the charge for transmitting remittances remains the problem to be overcome.

The Central Bank of Turkey plays a vital part in channelling the movements of staff to the nation as well as the Turkish commercial banks. The Bank provides each migrant with two separate bank accounts: (a) Foreign Currency Deposit Accounts and (b) Super FX Accounts. The Bank aimed at channelling remittances into deposits and investment in Turkey with higher interest rates than Turkish company banks for those unique accounts opened by migrants themselves. The cumulative sum of deposit earned in the Central Bank of Turkey

With respect to the Central Bank's long-term outlook, the very unusual transaction on remittances is seen as expensive accumulation and something outside of the Bank's key responsibility. Thus, it is deemed a factor which would be excluded from the bank's long-term liabilities. This is often noticed is that sending is very challenging to calculate when it is sent in a multitude of forms. While formal networks such as banks and transfers are used, informal mechanisms are still available, such as carriage of cash or cash and inkind items home to migrants. In the meanwhile, with respect to informal outlets of transmission, there is a variety of cited anecdotal proof that such religious companies or networks (often identified as "Islamic or Green" capital) engage in moving transactions to Turkey in an informal manner. Of note, informal remittances networks not only tend to be restricted in these situations. With respect to "new" financial goods, there are just a few small openings, one of them referring to the unique sales of Turkish Airlines shares to emigrants as part of the company's privatisation process. But there are less questions regarding providing a new financial commodity to draw remittances and proposing these products to promote local growth, with regard to the accumulated remittances deposits in the Central Bank of Turkey (approximately 14 billion euro).

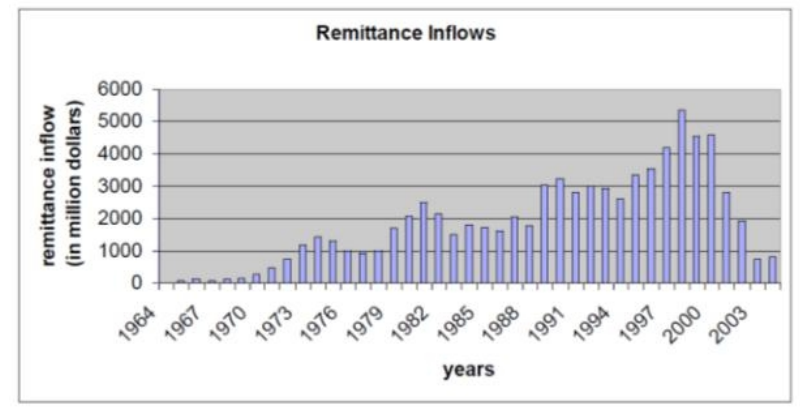

Figure 1: Flows of Remittances to Turkey, 19642004

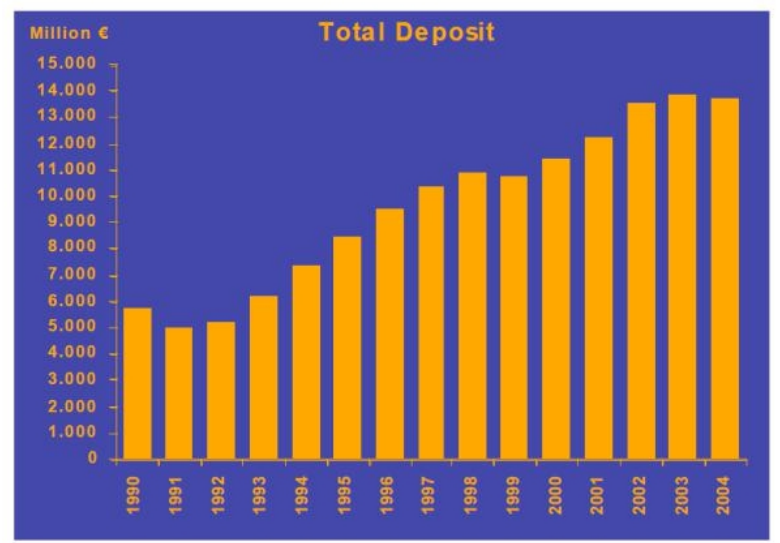

Figure 2: Foreign Currency Deposit Accounts and Super FX Accounts, 1990-2004 
Table 1: Overview of the remittance process (Source: Presentation by Nazlı Elif Köksal and Thomas Liebig (OECD), MiReKoc-OECD Workshop in Istanbul, 21 December 2004)

\begin{tabular}{|c|c|c|c|c|c|}
\hline & Turkish bank & & German banks & & Western Union \\
\hline & Is Bank & Ziraat Bank & $\begin{array}{l}\text { Sparkassen \& co- } \\
\text { operative banks }\end{array}$ & Postbank & \\
\hline $\begin{array}{l}\text { Most frequently } \\
\text { used transfer } \\
\text { modalities }\end{array}$ & $\begin{array}{l}\text {-"On-line" } \\
\text { transfer } \\
\text { proper to the } \\
\text { bank } \\
\text {-collective } \\
\text { accounts }\end{array}$ & $\begin{array}{l}\text { - electronic } \\
\text { transfer } \\
\text { proper to the } \\
\text { bank } \\
\text {-collective } \\
\text { accounts }\end{array}$ & $\begin{array}{l}\text { Swift transfer to a } \\
\text { Turkish bank }\end{array}$ & $\begin{array}{l}\text { Eurogiro } \\
\text { electronic } \\
\text { transfer } \\
\text { (international } \\
\text { Postal network) }\end{array}$ & $\begin{array}{l}\text { Worldwide online } \\
\text { system }\end{array}$ \\
\hline $\begin{array}{l}\text { Time for } \\
\text { transaction }\end{array}$ & $\begin{array}{l}-1 \text { hour } \\
-2-3 \text { days }\end{array}$ & $\begin{array}{l}-1 \text { day } \\
-2-3 \text { days }\end{array}$ & 4-5 days & about 6 six days & 1 hour \\
\hline $\begin{array}{l}\text { Costs of } \\
\text { remitting } \\
m €\end{array}$ & $\begin{array}{l}\mathbf{5 , 5} € \\
\text { if } m<5,000 € \\
\mathbf{8} € \\
\text { if } 5,000< \\
m<10,000 € \\
\mathbf{1 . 5} \% \text { of } \boldsymbol{m} \\
\text { if } m>10,000 €\end{array}$ & $\begin{array}{l}\mathbf{6} € \\
\text { if } m<5,000 € \\
\mathbf{1 . 5} \% \text { of } \boldsymbol{m} \\
\text { if } m>5,000 €\end{array}$ & $\begin{array}{l}\text { Differs from one } \\
\text { bank } \\
\text { to another. On } \\
\text { average, } \\
20 € \text { for } m=1,000 €\end{array}$ & $\begin{array}{l}15 € \text { for the first } \\
250 € \\
5 € \text { for each } \\
\text { additional } 250 €\end{array}$ & $\begin{array}{l}5 \% \text { of } m \\
\text { (with minimum } \\
26 \\
€, \text { maximum } 260 \\
€)\end{array}$ \\
\hline Remarks & $\begin{array}{l}\text { No further } \\
\text { fees in Turkey } \\
\text { only if money } \\
\text { is withdrawn } \\
\text { in } \\
\text { Turkish Lira }\end{array}$ & $\begin{array}{l}\text { No further fees } \\
\text { in Turkey if } \\
\text { money is } \\
\text { withdrawn in } \\
\text { Turkish Lira or } \\
m< \\
1,000 €\end{array}$ & $\begin{array}{l}\text { Additional fees } \\
\text { apply depending on } \\
\text { the correspon-dent } \\
\text { bank in Turkey. }\end{array}$ & $\begin{array}{l}\text { No further fees } \\
\text { in Turkey }\end{array}$ & $\begin{array}{l}\text { WU co-operates } \\
\text { with Postbank and } \\
\text { Reisebank in } \\
\text { Germany } \\
\\
\text { Current } \\
\text { promotion for } \\
\text { comissions (with } \\
\text { collaboration of } \\
\text { Reisebank) : } \\
6 € \text { if } m<500 € \\
2 \% \text { of } m, \text { if } \\
m>500 €\end{array}$ \\
\hline
\end{tabular}

\section{Impact of remittances on economic development}

While the send-off flows of the projected more than 3.5 million Turkish emigrants residing abroad to Turkey continue and potentially constitute a substantial part of the country's economic growth, the complex essence of the relation between the funds and economic development is still not so simple to recognise. Of instance, the major implications for a sending nation like Turkey of labour emigration include the advantageous effect of incoming workers' transfers. Turkey still wants external capital to finance infrastructure programmes, as a developing economy, and has been experiencing persistent international funds deficits to compensate for manufactured products and services and external debts. Through this view, the flow of funds from employees contributes significantly to the development of the world. While it is claimed that, in relation to these migrants' overall saving capacity, the volume of emigration transfers obtained by Turkey is somehow negligible, the size of transfers attributing to labour migration towards Europe remains high and one of the major foreign exchange sources. Job transfers rose from a tiny 93 million dollars in 1967 to a high of 1,4 billion dollars in 1974 and then decreased to 893 million dollars in 1978. Turkey has shown an annual collection of about \$1.52.0 billion between 1979 and 1988, at a more or less stable stage. In this time the payment receipts funded approximately one fourth of Turkey's annual gross import bill. The nation earned roughly $\$ 3.0$ billion annually in the late 1980 s and early 1990 s, rising to $\$ 3.4$ billion in 1995 . In the $1990 \mathrm{~s}$, transfers were equal to about $45 \%$ of the trade imbalance, but never surpassed 3\% of GNP. In brief, since the 1960 s workers' payments have contributed considerably to reaching the country's import bill, but their GNP contribution has still been quite small. 
Another feature of workers' funds was the form of contribution produced by migrants: money from abroad sometimes goes to help a family left behind or is invested as investment in machinery, construction, a vehicle or even as part of the effort by the migrant to develop himself in a trade or other new sector. Certainly, a great deal of wealth has gone straight through a migrant's families or surrounding society in order to sustain dependents remaining in Turkey. In several situations where migrants outside Turkey do not return, most of the money exchanged is expended on new home consumables. Transfers may not seem to be helpful in mitigating imbalances within regions within the world, while specific gains are apparent from transfers. Koc and Onan (2004)9 claim that, for example, remittances have a beneficial effect on the health of families, suggesting that households obtaining remittances are better off than nonremittances (See Tables 2). While substantial amounts of the related literature argue that remittances are not primarily expended on "productive investment" that will lead to longterm growth, it may also be argued that changes in migrants' living conditions such as improved access to nutrition or more money in schooling are some types of productive investment.

It is proposed that explicitly planned household surveys are necessary in different emigration regions in the world to gather information on cash flows and their effects on the economy. Two popular migration surveys are cited here:
Abadan-Unat et.al. research of Bogazliyan in 1976 and the 1996 Turkish Foreign Migration Survey in Turkey (TIMS96). TIMS-96 states that 12 percent of households earned transfers and 80 percent used transfers to raise their living conditions. These results have confirmed that geographical variations in the form of household transitions tend to be important. Households in less established regions are more likely than households in developed regions to earn transfers. These results suggest that recent migrant households appear to gain more funds in all regions regardless of their status of development10.

Saving transfers is known to be the first necessity to channel transfers into economic growth. When capital is saved in financial services, the likelihood of using it for different investment forms is assumed to improve, and as a consequence, it can have a beneficial influence on development11. More and more migrants have continued to submit money through formal networks, and more and more migrants have saved their money from banks, suggesting that the flow of money indirectly contributes to the country's growth.

The impact of transfers on regional growth is argued to be tougher to measure but is no longer regarded merely as a negative factor in the development of numerous migrantsending regions globally.

Table 2: The ways of spending remittances by region and household migration status (Source: Ismet Koc and Isil Onan (2004)

“International Migrants' Remittances and Welfare Status of the Left-Behind Families in Turkey”, International Migration Review, .38(1), pp. 78-112.)

\begin{tabular}{|c|c|c|c|c|c|}
\hline $\begin{array}{c}\text { Migration } \\
\text { status/remittances }\end{array}$ & $\begin{array}{l}\text { Developed- } \\
\text { Established } \\
\text { Migration } \\
\text { Region (1) }\end{array}$ & $\begin{array}{l}\quad \text { Less } \\
\text { Developed- } \\
\text { Established } \\
\text { Migration } \\
\text { Region (2) } \\
\end{array}$ & $\begin{array}{l}\text { Developed- } \\
\text { Recent } \\
\text { Migration } \\
\text { Region (3) } \\
\end{array}$ & $\begin{array}{l}\text { Less } \\
\text { Developed- } \\
\text { Recent } \\
\text { Migration } \\
\text { Region (4) } \\
\end{array}$ & Total \\
\hline \multicolumn{6}{|l|}{ Current migrant hh } \\
\hline Daily expenses & 80,0 & 82,5 & 64,3 & 64,7 & 75,0 \\
\hline Land/house & 0,0 & 2,5 & 0,0 & 5,9 & 2,6 \\
\hline Medical expenses & 0,0 & 2,5 & 28,6 & 11,8 & 9,2 \\
\hline Marriage expenses & 0,0 & 7,5 & 0,0 & 0,0 & 3,9 \\
\hline Other items & 20,0 & 5,0 & 7,1 & 17,6 & 9,2 \\
\hline \multicolumn{6}{|c|}{ Recent current migrant hh } \\
\hline Daily expenses & 75,0 & 75,0 & 66,7 & 71,4 & 72,4 \\
\hline Land/house & 0,0 & 3,6 & 0,0 & 7,1 & 3,4 \\
\hline Medical expenses & 0,0 & 3,6 & 25,0 & 14,3 & 10,3 \\
\hline Marriage expenses & 0,0 & 10,7 & 0,0 & 0,0 & 5,2 \\
\hline Other items & 25,0 & 7,1 & 8,3 & 7,1 & 8,6 \\
\hline
\end{tabular}




\begin{tabular}{|c|c|c|c|c|c|}
\hline \multicolumn{6}{|c|}{ Non-recent current migrant hh } \\
\hline Daily expenses & 50,0 & 100,0 & 0,0 & 33,3 & 76,5 \\
\hline Land/house & 0,0 & 0,0 & 100,0 & 0,0 & 0,0 \\
\hline Medical expenses & 0,0 & 0,0 & 0,0 & 0,0 & 5,9 \\
\hline Marriage expenses & 0,0 & 0,0 & 0,0 & 0,0 & 0,0 \\
\hline Other items & 50,0 & 0,0 & 0,0 & 66,7 & 17,6 \\
\hline \multicolumn{6}{|l|}{ Return migrant hh } \\
\hline Daily expenses & 75,0 & 80,0 & 0,0 & 100,0 & 76,7 \\
\hline Land/house & 25,0 & 0,0 & 0,0 & 0,0 & 3,3 \\
\hline Medical expenses & 0,0 & 0,0 & 33,3 & 0,0 & 3,3 \\
\hline Marriage expenses & 0,0 & 13,3 & 0,0 & 0,0 & 6,7 \\
\hline Other items & 0,0 & 6,7 & 66,7 & 0,0 & 10,0 \\
\hline \multicolumn{6}{|c|}{ Recent return migrant hh } \\
\hline Daily expenses & 66,7 & 90,0 & 0,0 & 100,0 & 73,7 \\
\hline Land/house & 33,0 & 0,0 & 0,0 & 0,0 & 5,3 \\
\hline Medical expenses & 0,0 & 0,0 & 33,3 & 0,0 & 5,3 \\
\hline Marriage expenses & 0,0 & 0,0 & 0,0 & 0,0 & 0,0 \\
\hline Other items & 0,0 & 10,0 & 66,7 & 0,0 & 15,8 \\
\hline \multicolumn{6}{|c|}{ Non-recent return migrant hh } \\
\hline \multicolumn{6}{|l|}{ Daily expenses } \\
\hline & 100,0 & 50,0 & - & 100,0 & 80,0 \\
\hline Land/house & 0,0 & 0,0 & - & 0,0 & 0,0 \\
\hline Medical expenses & 0,0 & 0,0 & - & 0,0 & 0,0 \\
\hline Marriage expenses & 0,0 & 50,0 & - & 0,0 & 20,0 \\
\hline Other items & 0,0 & 0,0 & - & 0,0 & 0,0 \\
\hline \multicolumn{6}{|l|}{ Non-migrant hh } \\
\hline Daily expenses & 86,7 & 94,7 & 57,1 & 83,3 & 84,9 \\
\hline Land/house & 0,0 & 0,0 & 0,0 & 16,7 & 3,8 \\
\hline Medical expenses & 0,0 & 5,3 & 42,9 & 0,0 & 7,5 \\
\hline Marriage expenses & 6,7 & 0,0 & 0,0 & 0,0 & 1,9 \\
\hline Other items & 6,7 & 0,0 & 0,0 & 0,0 & 1,9 \\
\hline \multicolumn{6}{|l|}{ Total } \\
\hline Daily expenses & 83,3 & 86,1 & 59,1 & 78,4 & 80,0 \\
\hline Land/house & 4,2 & 1,4 & 0,0 & 8,1 & 3,2 \\
\hline Medical expenses & 0,0 & 2,8 & 31,8 & 5,4 & 7,1 \\
\hline Marriage expenses & 4,2 & 6,9 & 0,0 & 0,0 & 3,9 \\
\hline Other items & 8,3 & 2,8 & 9,1 & 8,1 & 5,8 \\
\hline
\end{tabular}

\section{Maximizing the benefits: best practices and policy implications}

While in the 1970s and the 1980s there were some aggressive policies and practises to attract funds and redirect them into economic development, over the years12 they were not so effective in their service.

In the 1970s, the Turkish government sought to channel remittance savings on jobs to maximise economic development. In reality, there were three unique emigrationrelated creation projects. Firstly, the Turkish governments also promoted the formation of workers' joint stock 
companies to invest in the less developed regions of the world, beginning in the early emigration era, to guide the less developed funds rather than the developed. Investments by these firms are assumed to give returning migrants work prospects while also acting to economise their savings. This was seen as an important way to industrialise the regions of birth. More than 600 workers' companies with varying capital and number of shareholders have therefore been created. Although workers' companies strive to achieve a certain social objective by generally developing backward areas, they cannot avoid the economic considerations that matter considerably in companies' efficient activity. Workers' firms have been faced with numerous challenges, such as mission recognition, financial and technological preparation, and coordination inadequacy. Their position was therefore limited in encouraging the growth of less developed areas. Any 20 to 30 working business workers already operate in Turkey, but they are not properly managed and running businesses.

Another element of the official strategy for the reintegration into the local economies of returned migrants' savings was promoting village growth cooperatives. Since many of them preferred to secure employment for their representatives instead of investing productively in the villages through transfers, most of the co-operatives were used to encourage further migration. The creation of the State Industry and Workers' Investment Bank in 1975 was a third tool for attracting migrant savings. The bank promoted public- and private capital integrated mixed businesses, including workers' transfers. This initiative has not been successful either for businesses in general or for channelling investment capital into the less established areas.

In Turkish emigration's four decades of history the following policies, steps and practises to boost the development effects of transfer (a) promote transfer through institutional networks via foreign exchange accounts, premium rate and remittance bonds, and (b) contribute through matched funding to the collectives or associations of migrants;

Some researchers concluded that remittances cannot be effective instruments for sustainable development within the present international economic policy context. Even if they retained their high levels or would rise in the years to come, they would not meet their maximum capacity regarding their contribution to the nation's growth unless a new policy structure was introduced. In this sense, new policies on new practises must be encouraged at three levels: (a) to render sending mecanisms more efficient; that is, to submit money rapidly and at the lowest possible cost; (b) to raise remittance levels; and (c) to optimise remittance benefits for regional and national growth. Other participants indicated that any pro-active interventions were not required in this case. It is said that ineffective government intervention will be most unwanted amid migrants' mistrust in their governments.

While the government policies are also seen as a big factor impacting the changing rate of transfers and how they are transported, there is actually little possibility of a pro-active effort on the government side to get the transfers underway and to ensure the viability of the transfers.

\section{Conclusions}

During the period 1970-2013, we analysed the effect of remittances, FDI imports, and gross domestic savings on Turkey's economic growth using the ARDL method cointegration test.

The co-integration test showed that economic development, remittances, FDI inflows and gross domestic savings have long been associated. In the other side, the long-term coefficients of the ARDL model suggest that transfer rates, FDI inflows and gross domestic deposits have a beneficial influence on economic development.

Different sources have underlined the changing patterns in payments to Turkey in the last three to four years. This fall is stressed, partially due to an economic downturn in host countries such as Germany, which contributed to a stagnation in sales growth and increasing unemployment among Turkish emigrants. It is also stressed that payments would possibly begin to decline drastically, as more Turkish refugees enter the host countries and take fewer money off. What may be helpful in the sense of the Turkish situation of remittances-development ties is the following: a) awareness of the variety of forms of remittance: including intra-family transfers, personal transfers, mutual transfers or social security transfers; b) recognition of opposite objective.

\section{References}

1. Ahamada, I., Coulibaly, D. (2013) Remittances and growth in Sub-Saharan African countries: Evidence from a panel causality test, Journal of International Development, no. 25 , pp.310-324.

2. Arı, A., Ozcan, B. (2012) İşçi gelirleri ve ekonomik büyüme ilişkisi: Dinamik panel veri analizi, Erciyes Üniversitesi İktisadi ve İdari Bilimler Fakültesi Dergisi, no. 38, pp. 101-117.

3. Chami, R., Fullenkamp, C., Jahjah, S. (2003) Are immigrant remittances flows a source of capital for development?, IMF Working Paper, no.189.

4. Chowdhurya, M.B., Rabbi, F. (2014) Workers' remittances and Dutch Disease in Bangladesh, The Journal of International Trade \& Economic Development: An International and Comparative Review, no.23 (4), pp.455475 .

5. Dickey, D.A., Fuller, W.A. (1981) Distribution of the estimators for autoregressive time series with a unit root, Econometrica, no.49, pp.1057-1072.

6. Engle, R.F., Granger, C.W.J. (1987) Co-integration and error correction: Representation, estimation and testing, Econometrica, no.55(1), pp.251-276. 
7. Giuliano, P., Ruiz-Arranz, M. (2009) Remittances, financial development, and growth, Journal of Development Economics, no.90, pp.144-152.

8. Goschin, Z. (2014) Remittances as an economic development factor: Empirical evidence from the CEE countries, 7th International Conference on Applied Statistics, Procedia Economics and Finance, no.10, pp.5460.

9. IMF (2005) World Economic Outlook: Globalization and External Imbalances, IMF:Washington.

10. Johansen, S. (1988) Statistical analysis of cointegration vectors, Journal of Economic Dynamics and Control, no.12(2-3), 231-254.

11. Johansen, S. Juselius, K. (1990) Maximum likelihood estimation and inference on cointegration - with applications to the demand for money, Oxford Bulletin of Economics and Statistics, no.52, pp.169-210.

12. Karagöz, K. (2009) Workers' remittances and economic growth: Evidence from Turkey, Journal of Yasar University, no.4(13), 1891-1908.

13. Kumar, R.R., Stauvermann, P.J. (2014) Exploring the nexus between remittances and economic growth: A study of Bangladesh, International Review of Economics, no. 61(4), pp. 399-415.

14. Lim, S., Simmons W.O. (2015) Do remittances promote economic growth in the Caribbean Community and Common Market?, Journal of Economics and Business, no.77, pp.42-59.

15. López, H., Molina, L., Bussolo, M. (2007) Remittances and the real exchange rate, World Bank Policy Research Working Paper, No. 4213, Washington: World Bank.

16. Narayan, Paresh Kumar (2005) The saving and investment nexus for China: Evidence from cointegration tests, Applied Economics, no.37, pp.1979-1990.

17. Nikas, C., Blouchoutzi, A. (2014) Emigrants' remittances and the "Dutch Disease" in small transition economies: the case of Albania and Moldova, Revista Română de Statistică, no.1/2014, pp.45-65.

18. Nsiah, C., Fayissa, B. (2011) Remittances and economic growth in Africa, Asia, and Latin American-Caribbean countries: A panel unit root and panel cointegration analysis, Journal of Economics and Finance, no. 37, pp.424-441.

19. Nyamongoa, E.M., Misati, R.N., Kipyegon, L., Ndirangu, L. (2012) Remittances, financial development and economic growth in Africa, Journal of Economics and Business, no.62, pp.240- 260.

20. Pesaran, M.M., Shin, Y. (1995) Autoregressive distributed lag modelling approach to cointegration analysis, DAE Working Paper Series No.9514.

21. Pesaran M.H., Pesaran B. (1997) Working with microfit 4.0. Camfit Data Ltf.: Cambridge.

22. Pesaran, M.H., Shin, Y., Smith, R. (2001) Bounds testing approaches to the analysis of level relationships, Journal of Applied Econometrics, no.16, pp.289-326.

23. Phillips, P. C. B., \& Perron, P. (1988) Testing for unit roots in time series regression, Biometrika, no.75, pp.335346.

24. Pradhan, G., Upadhyay, M., Upadhyaya, K. (2008) Remittances and economic growth in developing countries, The European Journal of Development Research, no. 20(3), pp.497-506.

25. Ramey, G., Ramey, V.A. (1995) Cross-country evidence on the link between volatility and growth, American Economic Review, no. 85 (5), pp. 1138-1151.

26. Ravinesh, K., Vu, H.T.T.V. (2014) Exploring the nexus between ICT, remittances and economic growth: A study of Vietnam, Journal of Southeast Asian Economies, no. 31(1), pp.104-120.

27. Salahuddin, M., Gow, J. (2015) The Relationship between economic growth and remittances in the presence of cross-sectional dependence, The Journal of Developing Areas, no.49(1), pp.207-221.

28. Senbeta, A. (2013) Remittances and the sources of growth, Applied Economics Letters, no.20, pp.572-580.

29. Woodruff, C.M., Zenteno, R. (2004) Remittances and micro enterprises in Mexico, Graduate School of International Relations and Pacific Studies Working Paper. 30. Dr. Halil Ibrahim POLAT, AN APPROACH TO THE IMPLEMENTATION OF THE LAW NO 6306 OF RISKY STRUCTURES AND IZMIR SAMPLE, GJESR, 5(5), 107113 
http://www.gjesr.com/Issues\%20PDF/Archive-2018/May-

2018/17.pdf

31. World Bank (2014) Migration and development brief 23,

http://siteresources.worldbank.org/INTPROSPECTS/Resour

ces/334934-

1288990760745/MigrationandDevelopmentBrief23.pdf,

accessed January 3, 2015. 31. World Bank (2015) World

development indicators, http://data.worldbank.org/data-

catalog/world-development-indicators, accessed February 15,

2015. 